\title{
Article title: Organizational Innovation, Technological Innovation, and Export Performance: The Effects of Innovation Radicalness and Extensiveness
}

\section{Author Details}

Author 1 Name: Goudarz Azar (corresponding author)

Department: College of Business, Arts \& Social Sciences, Brunel Business School

University/Institution: Brunel University London

Town/City: Uxbridge

Country: United Kingdom

Telephone number: +44(0)1895268138

E-mail address: goudarz.azar@brunel.ac.uk

Author 2 Name: Francesco Ciabuschi

Department: Department of Business Studies

University/Institution: Uppsala University

Town/City: Uppsala

Country: Sweden

Telephone number: $+46(0) 184711411$

E-mail address: francesco.ciabuschi@fek.uu.se

\section{Acknowledgments:}

We are grateful to the editor of International Business Review and the two anonymous reviewers for helpful and constructive comments. The data collection in this research project was funded by "Stiftelsen Olle Hakelius Stipendiefond”, grant no: 1165001, which is gratefully acknowledged. 


\title{
Organizational Innovation, Technological Innovation, and Export Performance: The Effects of Innovation Radicalness and Extensiveness
}

\begin{abstract}
This study focuses on the relevance of different types of innovation for firms' export performance. Despite ample research on the innovation-performance relationship, previous studies have mainly focused on technological innovations, leaving the effects of organizational innovations relatively unexplored. Hypotheses on the relationship between organizational and technological innovations and firm export performance are tested by structural equation modelling using data from 218 Swedish export ventures. The results indicate that organizational innovation enhances export performance both directly and indirectly by sustaining technological innovation. Moreover, by fine-graining our analysis of the mediating role of technological innovation, according to its radicalness and extensiveness, for organizational innovation, we show how the latter enhances both the radicalness and extensiveness of technological innovation although, notably, only extensiveness is actually beneficial for export performance. This study helps alleviate the scarcity of research examining the links among different types of innovation in relation to export performance and contributes to international business and marketing literature by generating new evidence regarding the mechanisms through which organizational and technological innovations may improve export performance.
\end{abstract}

Keywords: organizational innovation, technological innovation, export performance, innovation radicalness, innovation extensiveness, internationalization 


\section{Organizational Innovation, Technological Innovation, and Export Performance: The Effects of Innovation Radicalness and Extensiveness}

\section{Introduction}

Scholars have acknowledged the significance of exporting in the global economy (Dhanaraj \& Beamish, 2003; Singh, 2009). Exporting, one of the most common means of entering international markets, enables firms to employ non-utilized operating capacity, increase production efficiency and, in turn, profits, and to ensure survival in a highly globalized marketplace (Guan \& Ma, 2003; Katsikeas, et al., 1996; Matanda \& Freeman, 2009; Sousa, et al., 2008). Cavusgil and Zou (1994, p. 4) define export performance as "the extent to which a firm's objectives...with respect to exporting a product into a foreign market, are achieved through planning and execution of export marketing strategy." A firm uses export marketing strategies to manage the interplay of internal and external forces to meet the objectives of the export venture (Leonidou, et al., 2002). Accordingly, the determinants of export performance can be classified into internal factors (e.g., the characteristics of the firm and its management, and the export marketing strategy) and external factors (e.g., the characteristics of foreign and domestic markets) (Brouthers, et al., 2009; Katsikeas, et al., 2000; Sousa, et al., 2008).

Changes in the environment generally trigger changes in the firm's strategies. Contingency factors are variables exogenous to the focal firm that represent situational characteristics that the firm is not able to control or manipulate. Response variables represent the organizational or managerial actions in response to contingency factors. Therefore, firm performance depends on the appropriate matching of response variables to the given contingency factors (Lawrence \& Lorsch, 1967; Robertson \& Chetty, 2000). In this context, the fit between internal and external factors is expected to enhance firm export performance (Leonidou, et al., 2002; Zeithaml \& Zeithaml, 1988). According to Sousa, Lengler, and Martínez-López (2014), understanding the determinants of export performance is a crucial area of research not 
only for academics but also for practitioners and policymakers: "successful export operations are crucial to both the firm and national prosperity" (p. 501). Pla-Barber and Alegre (2007) argue that knowledge of the internal determinants of export performance, specifically innovation, is contradictory and warrants further research. This research focuses on the firm's innovation strategy employed in its export strategy, as a response factor to the contingencies presented in a foreign market environment (Damanpour, et al., 2009; Robertson \& Chetty, 2000; Sousa, et al., 2008).

Despite much research on the innovation-performance relationship, previous research has mainly focused on one type of innovation, i.e., technological innovation (Damanpour \& Aravind, 2011). However, Damanpour and Aravind (2011) argue that the adoption of a single type of innovation or even a set of innovations of "only one type" may not enable firms to fully realize the positive effects of innovation on performance. Aiming to better understand how firms cope with changes and uncertainties in the international environment to achieve superior export performance, we suggest the necessity to further examine the effects of introducing different types of innovations. Specifically, we argue that when studying the innovation-performance relationship it is important to consider both technological and organizational innovations together.

Previous research argues that organizational innovation can act as the prerequisite for and facilitator of the efficient use of technological innovation (Armbruster, et al., 2008; Damanpour \& Evan, 1984). Damanpour, et al. (2009, p. 651) state that "changes in the technical (operating) system of the organization should be coupled with changes in the social (administrative) system in order to optimize organizational outcome." However, the relationships among different types of innovation have rarely been investigated (Camisón \& Villar-López, 2014; Damanpour \& Aravind, 2011; Gunday, et al., 2011; Sanidas, 2005). Thus, drawing upon the literature on socio-technical system theory (Damanpour \& Evan, 
1984; Damanpour, et al., 2009), the present study seeks to develop and empirically test a framework that links different types of innovation and export performance. Specifically, we examine the relationship between organizational and technological innovations and the direct and indirect effects of those innovations on export performance.

Moreover, to further enhance our understanding of this complex relationship we put forward a second important distinction in terms of innovation dimensions, i.e., the degree of innovation radicalness and the extensiveness of innovations. Both these dimensions are researched in the area of technological innovation, and they contribute to explaining performance. Innovation radicalness refers to the degree to which innovations depart from existing structural and technological principles (Damanpour \& Aravind, 2011), while innovation extensiveness ${ }^{1}$ refers to the number of innovations that a firm adopts within a given period (Damanpour, 1991). According to Reinders, Frambach, and Schoormans (2010, p. 1127), the adoption of radical innovations is "crucial for firms to enhance their competitive position and to safeguard their long-term success." However, previous research has revealed that innovation extensiveness also enhances firm performance (Damanpour \& Gopalakrishnan, 1998; Gopalakrishnan, 2000).

Thus, to further develop our understanding of the relationship between organizational and technological innovation we intend to specifically examine the influence that organizational innovation has on the radicalness and extensiveness of adopted technological innovations, and whether these two distinct dimensions may influence export performance in different ways.

This study contributes to the international business and innovation literature by showing the different effects of both technological and organizational innovation on export performance.

\footnotetext{
${ }^{1}$ Innovation extensiveness has also been referred to as innovation rate and magnitude (Damanpour \& Evan, 1984; Gopalakrishnan, 2000).
} 
This knowledge is important because past research offers very little empirical evidence of the relationship between organizational innovation and firm performance (Mol \& Birkinshaw, 2009). Moreover, this study shows also how organizational innovation influences indirectly export performance through technological innovation. This result supports previous arguments that the adoption of organizational innovation creates an appropriate environment and facilitates the adoption of technological innovation, which, in turn, enhances firm performance (Damanpour \& Evan, 1984; Damanpour, et al., 1989). Finally, to the best of our knowledge, this is the first study that simultaneously investigates the differential effects of innovation radicalness and extensiveness on export performance. Our study sheds new light on these two dimensions of innovation by determining which is more subject to organizational innovation influence and which is more important for export performance.

\section{Theoretical background and hypothesis development}

Innovation is a multifaceted construct that encompasses the generation, development, and implementation of an idea or behavior that is new to the adopting organization (Damanpour, 1996). During the innovation process, ideas are transformed into new products or services, new process technologies, new organizational structures, or new managerial approaches (Damanpour \& Aravind, 2011; Damanpour \& Evan, 1984).

A variety of innovation typologies have been proposed (Damanpour, et al., 2009). The technological-organizational typology ${ }^{2}$ is popular among management researchers and refers to a general distinction between the firm's technological and administrative systems, in which the former mainly produces changes in the firm's operating system and the latter mainly influences its management systems (Damanpour \& Aravind, 2011). According to Damanpour and Evan (1984, p. 394), technological innovation refers to "the implementation of an idea

\footnotetext{
${ }^{2}$ Technological innovation is also called 'technical' innovation. Organizational innovation has been referred to as administrative, managerial, management and non-technological innovation (Damanpour \& Aravind, 2011; Damanpour \& Evan, 1984; O'Cass \& Weerawardena, 2009).
} 
for a new product or a new service or the introduction of new elements in an organization's production process or service operation.”

Unlike technological innovation, the concept of organizational innovation is described by a variety of definitions. For instance, Birkinshaw et al. (2008, p. 829) define organizational innovation as "the generation and implementation of a management practice, process, structure, or technique that is new to the state of the art and is intended to further organizational goals." Damanpour and Evan (1984) talk instead about "administrative innovation" as innovation that occurs in the social system of an organization (e.g., new rules, roles, procedures, and structures); while Hamel (2006, p. 3) refers to the term "management innovation" as "a marked departure from traditional management principles, processes, and practices or a departure from customary organizational forms that significantly alters the way the work of management is performed." In this research, we have adopted the definition proposed by Damanpour and Aravind (2011, pp. 429-432) in which organizational innovation refers to "new approaches in knowledge for performing the work of management and new processes that produce changes in the organization's strategy, structure, administrative procedures, and systems," which should benefit the organization's teamwork, information sharing, coordination, collaboration, learning and innovativeness (Gunday, et al., 2011). Another established important distinction in terms of innovation typologies is the degree of innovation radicalness. Innovation radicalness refers to the degree to which innovations are ground breaking and disruptive ${ }^{3}$ and trigger "fundamental changes in the outputs or internal activities of the organization" (Damanpour \& Aravind, 2011, p. 436). In addition, to better understand different types of innovation effort in relation to each other and to performance, it

\footnotetext{
${ }^{3}$ Some scholars have distinguished between dis ruptive and radical innovations, arguing that the former refers to "introducing a different set of features and performance attributes relative to the existing products and being offered at a lower price" (Govindarajan \& Kopalle, 2006, p. 13).
} 
is also important to think about the extensiveness of innovation. Innovation extensiveness refers to the number of new products, new process technologies, new organizational structures, or new managerial approaches that a firm adopts within a given period (Damanpour, 1991).

In the remainder of this section we will focus on formulating hypotheses on the relationships between different types of innovation and export performance. Once we have established the distinction between organizational and technological innovations, our intent is to elaborate on the dimensions of radicalness and extensiveness of technological innovation. This enables us to further specify the direct and indirect effects of organizational innovation on different types of technological innovation and thereafter on performance.

\subsection{Organizational innovation and technological innovation}

According to socio-technical system theory, any change in an organization's technological system requires changes in the administrative system to adjust to the demands created by the technological system. In other words, organizational innovation is a necessary precondition for technological innovation to be fully implemented and exploited (Damanpour, et al., 1989; Lam, 2005). Lam (2005, p. 115) states that "the ability of an organization to innovate is a precondition for successful utilization of ... new technologies." Organizational innovations, in terms of structural improvements and organizational changes (e.g., policies, practices and communication) lead to enhanced intra-organizational coordination and cooperation, which, in turn, create an appropriate environment for the adoption and utilization of technological innovations (Damanpour \& Evan, 1984). According to Damanpour et al. (1989), the successful implementation of technological innovations depends on adopting changes in the administrative components of the organization (i.e., organizational innovations). Moreover, Teece (2010) argues that, to profit from technological innovations, enterprises must adopt 
new organizational forms, new organizational methods, and new business models that are of equal (if not greater) importance to the business enterprise.

However, the importance of organizational innovations in relation to new technological changes (innovations) is all too often underappreciated (Damanpour \& Evan, 1984). Since the seminal work of Damanpour and Evan (1984), only a few scholars have made an effort to examine the complex relationships among innovation types (Camisón \& Villar-López, 2014; Lam, 2005). In their study of libraries, Damanpour and Evan (1984) highlighted the need to train the staff in the cataloguing department and to devise new procedures for cataloguing library materials (as organizational innovation) to facilitate the digitalization of a card catalogue system (as technological innovation). In an empirical study of manufacturing firms in Turkey, Gunday et al. (2011) found that structural improvements effected by organizational innovations (for example, introducing a new organizational structure to facilitate teamwork and project type organization, introducing a new human resources management system) lead to enhanced intra-organizational coordination and cooperation mechanisms, which, in turn, create an appropriate environment for the adoption of process innovation. According to Hamel (2006), developing the industrial research laboratory as an organizational innovation has given rise to many patented technological innovations over the years for General Electric.

So, building on the argument that organizational innovation is beneficial for technological innovation, we intend to increase our understanding of their relationship by fine graining the effects of organizational innovation on different types of technological innovation. A first key dimension in defining a technological innovation is its degree of radicalness. Previous research maintains that the adoption of radical technological innovation requires new organizational procedures, routines, capabilities, management practices, and marketing skills, i.e., organizational innovation (Chandy, et al., 2003; Macmillan, et al., 1985; McDermott \& 
O'Connor, 2002; O'Connor \& Veryzer, 2001). Accordingly, established firms often fall behind start-ups in adopting radical innovations because of difficulties in breaking away from rigid organizational routines and cultures and transforming their current core capabilities into core rigidities (Chang, et al., 2012; Nijssen, et al., 2005). In other words, high levels of organizational memory, i.e., "repository for collective insights contained within policies, procedures, routines, and rules" (Day, 1994, p. 44) can inhibit a firm creativity (Moorman \& Miner, 1997). Bao et al. (2012) argue that the development of radical innovations requires resource allocation and the recognition of market opportunities that necessitate a paradigm shift in organizational mental models. Furthermore, Sainio, Ritala, and HurmelinnaLaukkanen (2012) and Teece (2010) argue that radical technological innovation demands new business models to support the exploitation and application of those innovations. However, not only the radicalness of technological innovation, but also the number of adopted technological innovations (i.e., innovation extensiveness) is suggested to be subject to variation when firms adopt organizational innovations (Damanpour \& Evan, 1984). Accordingly, innovation extensiveness is a second important dimension of technological innovation to account for. Damanpour and Evan (1984) suggest that adopting organizational innovation results in a high extent of technological innovation. Firms that embrace organizational change as an on-going effort and part of their organizational routines are consequently keen to foster continuous improvements also in the technological sphere, which leads to constant learning and serial innovation (Golgeci \& Ponomarov, 2013). At a general level, adopting organizational innovation enhances a firm's overall innovativeness (Gunday, et al., 2011), and empirical studies suggest specifically that adopting organizational innovation in the form of a new organizational structure influences the number of adopted technological innovations (Love \& Ashcroft, 1999; Wakasugi, 1992). Therefore, based on the above reasoning we hypothesize the following: 
$\mathrm{H}_{1}$ : The adoption of organizational innovation for the development of a foreign market is positively associated with both the (a) radicalness and (b) extensiveness of technological innovation.

\subsection{Innovation and export performance}

Innovation is a crucial component of a firm's strategy (Gunday, et al, 2011) and a source of competitive advantage in international markets (Pla-Barber \& Alegre, 2007; Singh, 2009). A review of empirical studies between 1984 and 2003 has shown that innovation is positively associated with firm performance (Walker, 2004). Firms adopt innovations to gain first or early mover advantages that will lead to superior performance (Damanpour, et al, 2009) or to eliminate a performance gap caused by uncertainties in the external environment (Damanpour \& Evan, 1984).

Changes and uncertainty in the firm's environment motivate organizations to seek strategic changes (Lawrence \& Lorsch, 1967), and innovation is a way of creating such change to ensure adaptive behavior (Damanpour, et al, 2009). Firms adopt innovation to adjust internal functions to respond to environmental demands, operate efficiently and effectively, and improve their performance, especially under conditions of uncertainty and a rapidly changing market environment (Damanpour \& Evan, 1984; Damanpour, et al., 2009). Scholars argue that innovations are growth strategy instruments for firms that seek to enter new markets, and they lead to an increase in the existing market share (Gunday, et al., 2011; C. H. Wang, et al., 2008). According to Alvarez (2004), increased productivity and the development of new goods as a result of innovations enhance a firm's export status. Moreover, innovativeness enables firms to respond quickly to market changes or to act on market offers before their competitors (Zahra \& Covin, 1995). The latter is very important because rapid changes in technologies and increasing competition in global markets erode the value added by existing products and services (Gunday, et al., 2011). 


\subsubsection{Different innovation typologies and export performance}

A balanced portfolio of both technological and organizational innovations is necessary to cope with changes and uncertainties in the environment and to fully realize the positive effects of innovation on performance (Damanpour \& Aravind, 2011; Damanpour, et al., 2009). However, as already mentioned, past research has primarily focused on technological innovation (D'Angelo, 2012; Hortinha, et al., 2011; Lages, et al., 2009; Roper \& Love, 2002; Singh, 2009; Y. Wang, et al., 2013), leaving the effect of organizational innovation on export performance rather unexplored (Armbruster, et al., 2008; Birkinshaw, et al, 2008;

Damanpour \& Aravind, 2011; Damanpour \& Evan, 1984; Han, et al., 1998; Weerawardena, 2003a, 2003b). A possible explanation for this shortcoming is that in relation to organizational innovations, technological innovations are generally perceived to have a clearer association with performance. Moreover, technological innovations are often more visible and less complex to implement (Damanpour \& Evan, 1984). Furthermore, few companies (if any) have well-established processes for continuous organizational innovations, whereas most businesses have a formal methodology for technological innovations, with many R\&D groups that explore the frontiers of science (Camison, 2005; Hamel, 2006; Mol \& Birkinshaw, 2009).

According to Hamel (2006), as with technological innovation, organizational innovation can provide sustained competitive advantages for the firm. Firm resources are stocks of tangible and intangible assets that are owned and controlled by the firm (Amit \& Schoemaker, 1993; Grant, 1991). According to Amit and Schoemaker (1993, p. 35), capabilities refer to "a firm's capacity to deploy resources, usually in combination, using organizational processes, to affect a desired end." Barney (1991) maintains that rare, valuable, non-substitutable and inimitable resources and capabilities are strategically relevant and can create differentiation and produce a competitive advantage for the firm. Accordingly, "the adoption of sets of innovations 
types... would provide the organization with required capabilities and distinctive competencies to continually outperform other organizations in its population" (Damanpour, et al., 2009, p. 656).

Adopting technological innovation is necessary but insufficient to achieve success and address new challenges in today's globally competitive environment (Teece, 2007). Dynamic management and organizational capabilities that effectively coordinate and redeploy internal and external resources towards the changing environment are required to support international expansion. Adopting organizational innovation results in changes in strategy, structure, and administrative procedures that improve, inter alia, the organization's climate, communication, personnel policies, teamwork, information sharing, and coordination and cooperation mechanisms (Damanpour \& Aravind, 2011; Gunday, et al., 2011), all of which can enhance a firm's performance. Sainio, et al. (2012) state also that a firm might utilize existing technology with a new business model and succeed. General Electric's 'industrial research laboratory,' DuPont's development of 'capital-budgeting techniques,' and Linux's 'open source development' are examples of organizational innovations that have been fundamental to those companies' successes (Hamel, 2006). Thus, we hypothesize the following:

$\mathrm{H}_{2}$ : The adoption of organizational innovation for the development of a foreign market is positively associated with firm export performance.

The influence of technological innovation on export performance is a result of the competitive advantages that firms obtain via new technologies, more efficient production techniques, and the new products and processes that result from these innovations (Hall \& Mairesse, 1995; Kafouros, et al., 2008; Zahra \& Covin, 1995). According to Zahra and Covin (1995) and Gunday et al. (2011), technological innovations enable firms to quickly respond 
to rapid changes in technologies and the market environment in highly competitive global markets.

Previous research suggests that the level of both innovation radicalness and extensiveness may be crucial for a firm's success in the shifting global marketplace. Scholars have proposed that radical innovations are developed in firms that have experimental cultures, entrepreneurial climates, and strong technical competencies (Damanpour \& Wischnevsky, 2006), which are often found in dynamic and competitive environments (Miller \& Friesen, 1982). The adoption of radical innovations enhances a firm's competitive position by offering novel functionalities and distinct customer benefits, which results in increased sales, profitability and market share. Radical innovation enables a firm to dominate the market with a new standard (Kimberly \& Evanisko, 1981; Nijssen, et al., 2005; O'Connor \& Rice, 2013; Reinders, et al., 2010; Sainio, et al., 2012; Tellis, et al., 2009). Innovation radicalness prevents rivals from learning about the innovation in question (Lee, et al., 2003). According to Zhou and Li (2012, p. 1090), "radical innovation reshapes the competitive landscape and creates new market opportunities." Bao et al. (2012) state that radical innovation fosters the growth and renewal of firms.

Still, as mentioned earlier, previous studies have indicated that not only the degree of innovation radicalness but also the adoption of a high number of innovations (i.e., innovation extensiveness) may enhance organizational effectiveness and competitiveness (Damanpour \& Gopalakrishnan, 1998). According to Gopalakrishnan (2000), there is a general agreement among scholars on that the "greater the number of innovations adopted, the more benefits accrue to the organization" (p. 139). Hurley and Hult (1998) state that the number of adopted innovations is an indication of a firm's innovative capacity (Cohen \& Levinthal, 1990); firms with greater innovative capacity are able to develop a competitive advantage and achieve better performance. The empirical studies by Han et al. (1998) and Subramanian (1996) 
confirm also at a general level that innovation extensiveness is positively associated with firm performance. Moreover, in the context of internationalization and export strategy, the notion of local adaptation and slow learning is key to performance (Cavusgil, et al., 1993; Johanson \& Vahlne, 1977); this idea fits well with the process of testing different products and offering variations. In other words, export performance may benefit from the introduction of a series of innovations as it provides room for trial and error, i.e., learning how to best serve and develop the foreign market. However, to the best of our knowledge, no previous study has simultaneously investigated the differential effects of innovation radicalness and extensiveness on a firm's export performance. Following the reasoning above, we hypothesize the following:

$\mathrm{H}_{3}$ : The (a) radicalness and (b) extensiveness of technological innovation adopted for the development of a foreign market are positively associated with firm export performance.

\subsubsection{The mediating role of technological innovation}

Damanpour et al. (2009) argue that pressures from the external environment, such as competition, isomorphism, and customer demand, are some of the main antecedents of the adoption of innovations to ensure a firm's adaptive behavior to maintain or improve its performance. Damanpour and Evan (1984) state that environmental changes influence organizational forms, which, in turn, affect the firm's technical systems. In other words, the adoption of organizational innovations in response to environmental changes and uncertainties (Armbruster, et al., 2008) results in changes in the organization's strategy, structure, administrative procedures, and systems that improve the organization's climate, communication, personal policies, teamwork, information sharing, coordination and collaboration, learning and innovativeness (Damanpour \& Aravind, 2011; Damanpour \& Evan, 1984; Gunday, et al., 2011; OECD, 2005). These changes enhance and facilitate the adoption of technological innovation (Damanpour \& Evan, 1984; Damanpour, et al., 1989). 
Thus, the introduction of new technologies, new products and new processes is the result of technological innovation efforts (Hall \& Mairesse, 1995; Kafouros, et al., 2008; Zahra \& Covin, 1995) enabled by organizational innovations. The effect of organizational innovation on export performance is therefore mediated by which technological innovations are enabled to respond to rapid changes and heterogeneity in technologies and markets. Thus, we propose the following hypothesis:

$\mathrm{H}_{4}$ : The (a) radicalness and (b) extensiveness of technological innovation adopted for the development of a foreign market mediate the relationship between organizational innovation and firm export performance.

\section{Research methodology}

\subsection{Data profile and research setting}

Our study sample consisted of 573 Swedish companies in the forestry, fishing, food product, beverage, garment, and furniture industries that satisfied the following criteria: (1) they had exported products for at least three years; and (2) they had exported to at least two foreign markets. The sample was selected randomly from a population of 963 companies using a stratified sampling method. This approach allowed us to include respondents in all the above industrial sectors in the study and thus obtain a more representative sample of the population (compared with, e.g., simple random sampling) (Robson, 2011). Sweden is well suited to the subject because it is a developed country with a very small domestic market and because its economy is extremely dependent on exporting to international markets. According to the World Bank's (2014) national accounts data, approximately 50\% of Sweden's GDP comes from the export of goods and services to international markets. The industries chosen are also well suited for the purpose of this study because a clear trend towards more international 
activities has been observed, particularly via exporting and particularly in the chosen industries in Sweden over the past decade (Statistics Sweden, 2012).

Moreover, these industries contribute a significant share of total manufacturing exports and a high share of employment and have a proven ability to innovate, giving them a vital role particularly in the developed economies of Western countries (Hirsch-Kreinsen, 2008). According to Mendonca (2009), in 2000, these industries accounted for approximately $48 \%$ of the total measured manufacturing R\&D in the entire OECD. Hirsch-Kreinsen's (2008) study of these industries suggests the presence of three typical innovation strategies: product innovation, production process innovation, and marketing innovation. In these industries, product innovation is generally characterized as incremental improvement in the materials, function, and quality of the product without departing from existing structural and technological principles (Damanpour, 1996). Product innovation is particularly essential in these sectors, where the products are often more connected to customer tastes, habits, and customs, which differ from market to market (Cavusgil \& Zou, 1994; Cavusgil, et al., 1993; Rama, 2008). Industries pursuing innovation in production processes are usually those with products manufactured with a high level of automation and those that use integrated process technologies to optimize production (e.g., the food, forestry, and fishery industries). Marketing innovation aims to improve the firm's market position and create new markets. This strategy is the most widely used for fashion- and design-oriented products that can respond rapidly to customer requirements (e.g., the garment and furniture industries) (Damanpour, 1996; Hirsch-Kreinsen, 2008).

Innovation activities in the aforementioned industries often involve the incorporation of hightech products and technologies, which demand a skilled workforce and can affect a firm's organizational structure and its interactions with other firms and public research institutions (OECD, 2005). Therefore, organizational innovations are particularly important in these 
sectors because companies are not normally the creators of integrated process technologies; rather they are often users of such innovations that were originally developed in other industries (Damanpour \& Evan, 1984). The adoption of organizational innovations thus facilitates the adoption of integrated process technologies (Damanpour \& Evan, 1984; Gunday, et al., 2011).

\subsection{Data collection procedure}

In this study, the data collection was conducted through TNS SIFO, a recognized marketing research agency in Sweden, from February to April 2012. A standardized structured questionnaire was designed for this study and was used to collect data from senior managers, who acted as key informants. We assumed that this group would provide more accurate responses for the purposes of this study because their position allows them to observe the entire organization (Glick, et al., 1990). The questionnaire was designed based on measures from the extant literature (Evans \& Mavondo, 2002; Evans, et al, 2008; Weerawardena, 2003a, 2003b) and modified for the current research context (Churchill, 1979). Additionally, two expert senior researchers reviewed and evaluated the questionnaire. We initially designed the questionnaire in English, and to reduce the risk of misinterpretation, it was then professionally translated into Swedish. The Swedish draft of the questionnaire was reviewed by the marketing research agency for minor modifications, after which it was translated back to English to double-check the correspondence of the terminology used in both languages.

We received 158 responses from 573 companies in the sample (approximately 28\%), which potentially amounted to 316 export ventures. Following Evans and Mavondo (2002) and Evans et al. (2008), the respondents were first asked to name two foreign markets to which their company had exported products over the previous three years, one that they perceived as "not so different" from their home market (Sweden) in terms of culture and business practices and one that they considered "different" from that of Sweden. These aspects are important 
because previous research has shown that differences in the cultural and business practices in foreign markets influence a firm's innovation strategies (Azar \& Drogendijk, 2014).

In the next stage, the respondents were asked to answer all the questions for both named export ventures. Accordingly, consistent with most recent studies, we assumed a single export venture as the unit of analysis in this study (Lages, et al., 2008; Lages, et al., 2009). Scholars argue that there are considerable variations in performance across various market export ventures of the same firm. Therefore, the same marketing strategy cannot lead to the same results in all export market ventures because external factors vary (Cavusgil \& Zou, 1994; Sousa, 2004). Accordingly, in contrast to firm-level analyses, using a single export venture as the unit of analysis allows us to analyze an export venture's specific contribution to export operations and, hence, accurately evaluate its contribution to overall export performance (Lages, et al., 2005; Morgan, et al., 2004). The complete case approach (listwise deletion) was used to handle missing data (Hair Jr., et al., 2010). The effective responses corresponded with 218 export ventures in 26 countries (see Appendix A for the list of export markets).

We tested for non-response bias by comparing early and late respondents (early respondents were defined as the first $75 \%$ to return questionnaires, and late respondents were defined as the last $25 \%$ ) in terms of the number of full-time employees, the number of years of exporting, the industry type, and the respondent's position. The lack of significant differences between the early and late respondents suggests that response bias was not a significant problem in the study (Armstrong \& Overton, 1977).

Furthermore, because the main variables in this study were collected from the same respondent, we used procedural and statistical remedies, as suggested by Podsakoff, MacKenzie, Lee, and Podsakoff (2003), to safeguard the findings against common method 
variance (CMV) (Fiske, 1982). In terms of procedural remedies, first, we used paper and pencil administrated questionnaires instead of conducting face-to-face interviews to gather data. Second, we protected respondent anonymity to reduce evaluation apprehension. Third, we improved scale items by defining the terms used in the questionnaires and provided examples to clarify the concepts. In terms of statistical remedies, we conducted Harmen's one-factor model test (Podsakoff, et al., 2003), in which a worse fit for the one-factor model would suggest that CMV did not pose a serious problem. The rationale of this test is that if CMV poses a serious threat to the analysis, then a single latent factor may account for all manifest variables (Podsakoff, et al., 2003). The one-factor model fit statistics indicated that this model did not fit the data, suggesting that CMV was not likely to be a problem threatening the findings.

In terms of the characteristics of the sample, most of the respondents were CEOs of firms with fewer than 50 full-time employees. Most of the firms in the sample had significant international experience and had engaged in export operations for an average of 20 years (SD $=14.5$, range $=2-97)$. The firms' average number of export markets was eight $(\mathrm{SD}=7.7$, range $=2-40$ ). Approximately $54 \%$ of the export ventures targeted other EU countries, while the remainder targeted non-EU countries. Firms in the food product and furniture industries were overrepresented in the sample (see Appendix B for more details about the sample's characteristics).

\subsection{Measures}

We based our measures on the extant literature and modified them for the current research context (Churchill, 1979). A list of all the constructs and measurement items is provided in Table 1.

**Insert Table 1 about here** 


\subsubsection{Organizational and technological innovation}

Previous research on innovation has often relied on secondary data (e.g., patents) or other proxy measures (e.g., R\&D intensity) to operationalize innovation (Archibugi \& Planta, 1996; Nam, et al., 2014). However, recent research emphasizes the need for more direct measures of innovative outputs (Nam, et al., 2014; Powell \& Grodal, 2005), not only because of the shortcomings of patents and R\&D intensity as measures of innovation (Freeman \& Soete, 2009), but also because of sectoral differences causing bias in the use of these indicators to measure innovation (Galizzi \& Venturini, 2008; Hervas-Oliver, et al., 2011).

In the present study, the scales used to measure organizational and technological innovation were based on those developed by Weerawardena (2003a, 2003b). We conceptualized the organizational innovation construct as a reflective construct (O'Cass \& Weerawardena, 2009), comprising managerial and marketing dimensions that are manifestations of the overall construct (Jarvis, et al., 2003). Likewise, we conceptualized technological innovation constructs, comprising product and process dimensions, as manifestations of the overall constructs. We asked the respondents to indicate the extensiveness $(1=\operatorname{limited}$ and $7=$ extensive $)$ and radicalness $(1=$ incremental and $7=$ radical $)$ of innovation that the firm had adopted for the development of the foreign market in the previous three-year period on a seven-point scale (Table 1).

This method enabled us to utilize primary sources of data related to innovation within firms and explore their actual innovation activities. Furthermore, compared with proxy measures for innovation (e.g., $R \& D$ intensity), this method was more appropriate for measuring innovation activities adopted by the companies in the sample, where R\&D expenditures were often low and, in turn, R\&D intensity would provide a misleading view (Hirsch-Kreinsen, 2008). 


\subsubsection{Export performance}

Despite extensive research on exporting, there are no definite and unambiguous guidelines for how to measure a firm's export performance (Brouthers, et al., 2009). Scholars have used both subjective and objective measures of export performance; however, most measures are self-reported based on managers' perceptions (Haahti, et al., 2005; Lages, et al., 2005).

Sousa (2004) argues that export performance is a multi-dimensional concept and that a reliable assessment of the construct thus requires multiple indicators. According to Cavusgil and Zou (1994), the extent to which an export venture's financial and strategic objectives are attained will determine its performance. Therefore, export performance in this study was measured using six items within two dimensions: financial performance and strategic effectiveness (Evans \& Mavondo, 2002; Evans, et al., 2008). Regarding financial performance, the respondents were asked to indicate the degree to which several financial indicators had changed over the last three-year period in the foreign market on a seven-point scale. We chose a three-year time frame to increase our confidence in the quality and reliability of the data provided by the respondents (Papadopoulos \& Martín Martín, 2010). We measured strategic effectiveness via two indicators, i.e., achievement of strategic objectives and satisfaction with overall performance (Evans \& Mavondo, 2002; Evans, et al., 2008) (Table 1).

\subsubsection{Control variables}

We used the natural logarithm of the number of full-time employees as a proxy for firm size, which is the most common measure of size in innovation and export research (Contractor, et al., 2005); we entered this proxy and industry type as control variables in the model. As a proxy for the extent of a firm's access to knowledge assets and critical resources for the innovation process, size may enhance the firm's ability to adopt innovations ( Kimberly \& Evanisko, 1981), both technological (Damanpour, 2010) and organizational (Mol \& 
Birkinshaw, 2009). Factors such as the flexibility and fluidity of communication may bring advantages to small firms that are developing innovations (Shefer \& Frenkel, 2005). A firm's size is also suggested to enhance its export performance. Utilizing economies of scale, access to specialized executives, their marketing and sales departments, and the possibility of financing at lower cost provide advantages for exporting firms to enhance their performance (Wagner, 1995, 2001).

Furthermore, we controlled for the host countries' R\&D expenditures (percentage of GDP) and statuses as developing/developed economies. ${ }^{4}$ Previous research proposes that the extent of the host countries' development influences the exporting firm's innovation strategies. Alvarez and Robertson (2004) found that firms that export to developing countries are more likely to have $R \& D$ units and to invest in product design, whereas firms that export to developed countries are more likely to invest in new products and production processes. The argument is that exporting to developed markets requires upgrading production processes (technology) to meet the markets' specifications, while exporting to developing markets demands leadership in product design and research (Gereffi, 1999). Finally, we inserted a dummy variable in the model that indicated whether the foreign market had been considered different/not so different from the home market in terms of cultural and business practices, as the perception of major differences in foreign markets may stimulate the adoption of innovations (Azar \& Drogendijk, 2014).

We assessed the measurement model properties and analyzed the structural model using maximum likelihood estimation (MLE) with LISREL 8.80 (Jöreskog \& Sörbom, 2006) (Table 1). We assessed all the measures of convergent validity by performing a confirmatory factor analysis and calculating the average variance extracted (AVE) (Fornell \& Larcker,

\footnotetext{
${ }^{4}$ Data for host countries' R\&D expenditures (percentage of GDP) and its extent of development were obtained from the World Bank (2014). Countries with a gross national income (GNI) of US\$11,905 or less are defined as developing countries (World Bank, 2014).
} 
1981) for all the constructs. All the AVE values were greater than 0.5 , indicating convergent validity. We assessed the constructs for internal consistency by calculating composite reliability (CR) (Bagozzi, 1980). All the constructs met the suggested minimum ${ }^{5}$ value for composite reliability (Hair Jr., et al., 2010). We assessed the individual items' reliabilities by examining the standardized loadings of items on their corresponding constructs. All the items loaded on their specified constructs, and each loading was large ( 0.5 is the minimum accepted value) and significant, which implies that all the items converged on a common construct (Gerbing \& Anderson, 1988). We determined the corresponding Cronbach's alpha values for all the constructs, as shown in Table 1 . All the values were greater than 0.8 , indicating high reliability and consistency for the entire scale ( 0.6 is the lower limit for Cronbach's alpha) (Hair Jr., et al., 2010).

For hypothesis testing, we have combined the items to develop additive scales for each construct of interest (Tellis, et al., 2009). Following our hypotheses building, for organizational innovation we have aggregated the extensiveness and radicalness of marketing and managerial innovations in a single construct, whereas we have operationalized technological innovation as two separate constructs: one measuring the extensiveness of product and process innovations (indicators with the suffix EXT), and the other measuring their radicalness (indicators with the suffix RAD) (Table 1). We assessed the validity and reliability of these two constructs. The AVE values 0.6 and 0.65 and Cronbach's alpha values 0.6 and 0.7 for the constructs technological innovation extensiveness and radicalness, respectively, confirmed that both constructs were sufficiently valid and reliable. The statistical properties of the constructs are reported in Table 2. To test for discriminant validity, we used the method recommended by Burnkrant and Page (1982). We compared the

\footnotetext{
${ }^{5}$ According to Hair, Jr. et al. (2010), a reliability estimate of higher than 0.7 suggests good reliability. A reliability between 0.6 and 0.7 is accepted if other validity indicators are good. The latter is applicable for the technological innovation construct.
} 
goodness of fit of two measurement models: one model based upon a perfect correlation (constrained at 1) among the (main) constructs (a one-factor model) and another model that does not consider this restriction (a four-construct model). The results clearly indicate the better fit of the non-restricted model $(\mathrm{CFI}=1$; RMSEA $=0.044)$ compared with that of the restricted model $(\mathrm{CFI}=0.78$; $\mathrm{RMSEA}=0.291)$, attesting to discriminant validity (Stoian, et al., 2011). Furthermore, we conducted a chi-square test to compare the measurement models. The results $\left(\Delta \chi^{2}=94.15, \Delta\right.$ d.f. $\left.=3, p<0.001\right)$ also established discriminant validity (Evans, et al., 2008).

**Insert Table 2 about here**

\section{$4 \quad$ Research findings}

We used a path model (Figure 1) with LISREL to jointly test all of the hypotheses. We controlled for firm size, industry type, host countries' R\&D expenditures (percentage of GDP), the firm's extent of development, and (perceived) market differences. All the indices indicated that the hypothesized model had adequate fit with the data (Figure 1).

$$
\text { **Insert Figure } 1 \text { about here** }
$$

$\mathrm{H}_{1}$ states that the adoption of organizational innovation for the development of a foreign market is positively associated with both the (a) radicalness and (b) extensiveness of technological innovation. The path coefficients between organizational innovation and both the radicalness $(\beta=0.62, p<0.05)$ and extensiveness $(\beta=0.67, p<0.05)$ of technological innovation are positive and significant, supporting $\mathrm{H}_{1}$. The positive and significant path coefficient $(\beta=0.20, p<0.05)$ between organizational innovation and firm export performance confirms $\mathrm{H}_{2} . \mathrm{H}_{3}$ states that the radicalness and extensiveness of technological innovation for the development of a foreign market are positively associated with firm export performance. The path coefficient between the extensiveness of technological innovation and 
export performance is positive and significant $(\beta=0.16, p<0.05)$ (supporting $\mathrm{H}_{3 \mathrm{~b}}$ ), whereas, surprisingly, the path coefficient between the radicalness of technological innovation and export performance is not statistically significant.

Regarding the control variables, firm size positively and significantly $(\beta=0.09, p<0.05)$ influences firm export performance. According to Wagner $(1995,2001)$, by utilizing economies of scale, access to specialized executives, and the possibility of financing at lower cost, larger firms can attain better performance. Moreover, the extent of the host country's development has a positive and significant influence $(\beta=0.11, p<0.05)$ on the extent of the radicalness of technological innovation. This result is consistent with previous studies that found that firms that export to developed countries are more likely to invest in technological innovations to meet the market's specifications (Alvarez \& Robertson, 2004).

To examine the extent to which the adoption of technological innovation radicalness and extensiveness mediate the effect of organizational innovation on export performance $\left(\mathrm{H}_{4}\right)$, we relied on the three-step approach recommended by Baron and Kenny (1986). To meet the first mediation condition, Figure 1 shows that organizational innovation is significantly related to both technological innovation radicalness and extensiveness, thus satisfying the first condition of mediation, i.e., variations in the mediators (technological innovation radicalness and extensiveness) significantly account for variations in the independent variable (organizational innovation). In the next step, in the absence of the mediators, we examined the relationship between organizational innovation and export performance. The results ${ }^{6}$ show that organizational innovation is significantly related to export performance $(\beta=0.35, p$ $<0.05)$ thus satisfying the second condition of mediation. Finally, as Figure 1 shows, after entering the mediators of technological innovation radicalness and extensiveness, the results

\footnotetext{
${ }^{6} \chi^{2}=17.80$ (10 d.f., $\left.\mathrm{p}=0.05850\right) ; \mathrm{RMSEA}=0.060 ; \mathrm{NFI}=0.93 ; \mathrm{CFI}=0.96 ; \mathrm{IFI}=0.97 ; \mathrm{RFI}=0.80 ; \mathrm{SRMR}=$ $0.044 ;$ GFI $=0.98 ;$ AGFI $=0.93$.
} 
indicated that only technological innovation extensiveness, and not radicalness, is significantly related to export performance $(\beta=0.16, p<0.05)$. Focusing on the significant path, we found that organizational innovation is still significantly related to export performance $(\beta=0.20, p<0.05)$ in the presence of the mediator (technological innovation extensiveness). However, we found that there is a substantial reduction in the path coefficient (from 0.35 to 0.20 ) and the $t$-value (from 7 to 3 ) for the direct link between organizational innovation and export performance after entering the mediator. Thus, technological innovation extensiveness partially ${ }^{7}$ mediates this link (Baron \& Kenny, 1986; L. Zhou, et al., 2007).

\section{Discussion and concluding remarks}

At a general level, the results of this study show that adopting innovations for the development of a foreign market is beneficial to export performance. New technologies, more efficient production techniques, and new products and processes resulting from technological innovation help exporting firms to respond to technological and environmental changes in highly competitive global markets (Hall \& Mairesse, 1995; Kafouros, et al., 2008; Zahra \& Covin, 1995). Furthermore, adopting organizational innovations in response to environmental changes and heterogeneity is beneficial for a firm export performance (Damanpour \& Aravind, 2011; Damanpour \& Evan, 1984; Gunday, et al., 2011; Hamel, 2006). Thus, this study confirms that innovation is a source of competitive advantage in international markets, which is a crucial antecedent of firm export performance (Pla-Barber \& Alegre, 2007; Sousa, et al., 2008).

However, we find evidence that in exporting activities, specifically organizational innovation is an important antecedent of technological innovation. This means that improvements-for

\footnotetext{
${ }^{7}$ A non-significant path between organizational innovation and export performance in the presence of the mediator would suggest that technological innovation extensiveness fully mediates the impact of organizational innovation on export performance (Baron \& Kenny, 1986).
} 
example in the firm's strategy, structure, administrative procedures, and systems - resulting from organizational innovations can enhance innovativeness and create an appropriate environment for the adoption of technological innovation (Damanpour \& Evan, 1984; Damanpour, et al., 1989). This finding is in line with Damanpour et al.'s (1989) suggestion that the successful implementation of technological innovations requires that the administrative component of the organization be open to new ideas and practices with which to enhance and facilitate the adoption of technological innovations. The results show that organizational innovation enhances technological innovation in terms of both its radicalness and extensiveness. Previous studies have suggested that the complex relationships among technological and managerial knowledge resources, as firms' internal resources, can lead to the introduction of different types of innovations that bring required capabilities and distinctive competencies to the firm and give it competitive advantages (Camisón \& VillarLópez, 2014). In this sense, our key findings contribute to previous research not only by highlighting the importance of adopting technological-organizational innovations (Damanpour \& Aravind, 2011; Damanpour, et al., 2009), but also by explicitly rendering the effects in terms of specific technological innovation outputs: innovation radicalness and extensiveness.

Moreover, our results show that technological innovation extensiveness partially mediates the link between organizational innovation and export performance. Notably, this finding means that structural improvements resulting from organizational innovation can improve firm export performance both directly and also via enhancing technological innovation extensiveness. In other words, this finding supports the argument that coping with changes and uncertainties in the environment and attaining superior performance require the introduction of both technological and organizational innovations (Damanpour, 2010; 
Damanpour \& Evan, 1984) and sheds new light on the relationship between organizational and technological innovation in relation to export performance.

Our study also shows a non-significant relationship between technological innovation radicalness and export performance. In fact, only technological innovation extensiveness shows a positive effect on performance. This result is in line with extant research arguing that adopting a high number of innovations may enhance innovative capacity, and consequently the firm's competitive advantage and performance (Cohen \& Levinthal, 1990; Hurley \& Hult, 1998). Moreover, an explanation for this result (i.e., the positive effect of extensiveness and no effect of radicalness) may lie in internationalization theory and radical innovation studies. A core aspect of the internationalization process model (Johanson \& Vahlne, 1977, 2009) is the firm's stepwise incremental behavior on internationalizing. If we consider innovation a strategic resource when entering a new market, then an innovation strategy is arguably affected by the firm's internationalization behavior. In other words, if a firm's internationalization process is characterized by small incremental steps, then the innovation strategy may also mimic this process by developing and introducing several small incremental innovations (instead of fewer radical ones) into a new market. A higher number of incremental innovations introduced to aid market entry via exports also fits well with another core aspect of the internationalization process model, that is, learning and adaptive behaviors, which are typically characterized by trial-and-error and slow learning (Forsgren, 2002; Johanson \& Vahlne, 1977). If market entry via exports is considered in terms of an early stage of an internationalization process, then it is clear how a lack of experiential knowledge (compared with firms with established foreign organizations) connects with trialand-error learning (Salomon \& Jin, 2008), which helps explain why the number of innovations has a positive effect on performance. It is not through major radical innovations that firms learn how to best act in a new market; instead, firms learn through a series of 
smaller innovations or simple changes and adaptations (Droge, et al., 2008). Some of the innovations introduced will work, while others will fail. The learning outcome will drive subsequent efforts, which will generate other innovations, thus enhancing the overall extensiveness of technological innovation.

This study also contributes to international marketing research by highlighting the effects of different innovations on export performance (Pla-Barber \& Alegre, 2007). When marketing new products or services in new markets, firms seemingly cannot limit themselves to technological innovations. Organizational innovations are equally (if not more) important for achieving higher export performance (Damanpour \& Aravind, 2011; Gunday, et al., 2011). However, when considering technological innovation, the extensiveness of innovations is more important than innovation radicalness. This result also finds support in previous research on radical innovation that explains how this type of innovation often requires major market changes and requires longer periods than incremental innovation to gain market acceptance and generate significant returns. This finding also suggests that it is more difficult for a firm to overcome market uncertainty related to new market entry with a strategy based on radical innovation, which is also highly uncertain in nature (Chang, et al., 2012; Droge, et al., 2008; Junkunc, 2007; O'Connor \& Veryzer, 2001). ${ }^{8}$

Our findings have several implications for international managers. The challenges related to expansion into foreign markets can be compensated by a firm's greater ability to differentiate itself through a series of incremental innovation efforts. It is important for managers to devote as much attention to developing innovations not only in terms of processes and

\footnotetext{
${ }^{8}$ It is noteworthy that some scholars have proposed a non-linear (inverted U-shaped) relationship between the adoption of technological innovation and firm performance. Although the introduction of radical technological innovations may provide firms with advantages, too much radicalness is not necessarily beneficial for businesses and could be harmful (Story, et al., 2015). To test this proposition, we (re)estimated the structural model using squared terms of technological innovation radicalness. However, the results appeared similar to those of the original model, i.e., the path between the radicalness of technological innovation and export performance was not statistically significant.
} 
products but also in terms of organizational strategy, structure, and administrative procedures. Adopting innovations is vital to ensure adaptive behavior by exporting firms. A fit between innovation strategies and foreign market characteristics and demands will then enhance the firm's export performance. However, managers should also be aware that adopting a higher number of smaller technological innovations enables exporting firms to better adjust to the new foreign environment and enhance their performances than focusing exclusively on radical innovations.

\subsection{Limitations and directions for further research}

This study provided some insights into innovation and export performance research; however, there were several limitations to the approach used. First, we used scales developed by Weerawardena $(2003 \mathrm{a}, 2003 \mathrm{~b})$ to measure firms' innovation activities. Although these scales have advantages (e.g., multidimensionality, capturing direct innovation activities fitting the sample of the study), future studies could perhaps apply more comprehensive measures of both technological and organizational innovations. Second, combining the objective measures of export performance with the subjective measures used in the current study may provide a more comprehensive picture of export performance. Third, the crosssectional method applied in this study could not capture the dynamic aspects of strategy formulation in international markets and the causality among constructs. Future studies should address the relationships proposed in the hypothesized model using longitudinal data to overcome such limitations and allow for more accurate evaluation of causality in the relationships among organizational innovation, technological innovation, and firm export performance. An especially important consideration is the empirical possibility that adopting technological innovations leads to organizational innovations. Previous research states that organizational innovations precede technological innovations; however, longitudinal research on this issue is still necessary and constitutes a fruitful direction for further research built on 
our findings. Finally, the composition of the sample may limit the generalizability of our findings because we restricted our study to Swedish companies in the forestry, fishing, food product, beverage, garment, and furniture industries. We suggest that future studies replicate this investigation in other regional and industrial contexts.

\author{
**Insert Appendix A about here** \\ **Insert Appendix B about here**
}

\title{
References
}

Alvarez , R. (2004). Sources of Export Success in Small- and Medium-Sized Enterprises: The Impact of Public Programs. International Business Review, 13, 383-400.

Alvarez, R., \& Robertson, R. (2004). Exposure to Foreign Markets and Plant-Level Innovation: Evidence from Chile and Mexico. Journal of International Trade \& Economic Development, 13, 57-87.

Amit, R., \& Schoemaker, P. J. H. (1993). Strategic Assets and Organizational Rent. Strategic Management Journal, 14, 33-33.

Archibugi, D., \& Planta, M. (1996). Measuring Technological Change through Patents and Innovation Surveys. Technovation, 16, 451-519.

Armbruster, H., Bikfalvi, A., Kinkel, S., \& Lay, G. (2008). Organizational Innovation: The Challenge of Measuring Non-Technical Innovation in Large-Scale Surveys. Technovation, 28, 644-657.

Armstrong, J. S., \& Overton, T. S. (1977). Estimating Nonresponse Bias in Mail Surveys. Journal of Marketing Research, 14, 396-402.

Azar, G., \& Drogendijk, R. (2014). Psychic Distance, Innovation, and Firm Performance. Management International Review, 54, 581-613.

Bagozzi, R. P. (1980). Casual Models in Marketing. New York: John Wiley \& Sons.

Bao, Y., Chen, X., \& Zhou, K. Z. (2012). External Learning, Market Dynamics, and Radical Innovation: Evidence from China's High-Tech Firms. Journal of Business Research, 65, 1226-1233.

Barney, J. (1991). Firm Resource and Sustained Competitive Advantage. Journal of Management, 17, 99-120.

Baron, R. M., \& Kenny, D. A. (1986). The Moderator-Mediator Variable Distinction in Social Psychological Research: Conceptual, Strategic, and Statistical Consideration. Journal of Personality and Social Psychology, 51, 1173-1182.

Birkinshaw, J., Hamel, G., \& Mol, M. J. (2008). Management Innovation. Academy of Management Review, 33, 825-845.

Brouthers, L. E., Nakos, G., Hadjimarcou, J., \& Brouthers, K. D. (2009). Key Factors for Successful Export Performance for Small Firms. Journal of International Marketing, 17, 21-38.

Burnkrant, R. E., \& Page, T. J., Jr. (1982). An Examination of the Convergent, Discriminant, and Predictive Validity of Fishbein's Behavioral Intention Model. Journal of Marketing Research, 19, 550-561. 
Camisón, C. (2005). On How to Measure Managerial and Organizational Capabilities: MultiItem Models for Measuring Distinctive Competences. Management Research, 3, 27 48.

Camisón, C., \& Villar-López, A. (2014). Organizational Innovation as an Enabler of Technological Innovation Capabilities and Firm Performance. Journal of Business Research, 67, 2891-2902.

Cavusgil, S. T., \& Zou, S. (1994). Marketing Strategy-Performance Relationship: An Investigation of the Empirical Link in Export Market Ventures. Journal of Marketing, $58,1-21$.

Cavusgil, S. T., Zou, S., \& Naidu, G. M. (1993). Product and Promotion Adaptation in Export Ventures: An Empirical Investigation. Journal of International Business Studies, 24, 479-506.

Chandy, R. K., Prabhu, J. C., \& Antia, K. D. (2003). What Will the Future Bring?

Dominance, Technology Expectations, and Radical Innovation. Journal of Marketing, 67, 1-18.

Chang, Y. C., Chang, H. T., Chi, H. R., Chen, M. H., \& Deng, L. L. (2012). How Do Established Firms Improve Radical Innovation Performance? The Organizational Capabilities View. Technovation, 32, 441-451.

Churchill, G. A., Jr. (1979). A Paradigm for Developing Better Measures of Marketing Constructs. Journal of Marketing Research, 16, 64-73.

Cohen, W. M., \& Levinthal, D. A. (1990). Absorptive Capacity: A New Perspective on Learning and Innovation. Administrative Science Quarterly, 35, 128-152.

Contractor, F. J., Hsu, C.-C., \& Kundu, S. K. (2005). Explaining Export Performance: A Comparative Study of International New Ventures in Indian and Taiwanese Software Industry. Management International Review, 45, 83-110.

D'Angelo, A. (2012). Innovation and Export Performance: A Study of Italian High-Tech SMEs. Journal of Management and Governance, 16, 393-423.

Damanpour, F. (1991). Organizational innovation: A meta-analysis of effects of determinants and moderators. Academy of Management Journal, 34, 555-590.

Damanpour, F. (1996). Organizational Complexity and Innovation: Developing and Testing Multiple Contingency Models. Management Science, 42, 693-716.

Damanpour, F. (2010). An Integration of Research Findings of Effects of Firm Size and Market Competition on Product and Process Innovations. British Journal of Management, 21, 996-1010.

Damanpour, F., \& Aravind, D. (2011). Managerial Innovation: Conceptions, Processes, and Antecedents. Management and Organization Review, 8, 423-454.

Damanpour, F., \& Evan, W. M. (1984). Organizational Innovation and Performance: The Problem of "Organizational Lag". Administrative Science Quarterly, 29, 392-409.

Damanpour, F., \& Gopalakrishnan, S. (1998). Theories of Organizational Structure and Innovation Adoption: The Role of Environmental Change. Journal of Engineering and Technology Management, 15, 1-24.

Damanpour, F., Szabat, K. A., \& Evan, W. M. (1989). The Relationship between Types of Innovation and Organizational Performance. Journal of Management Studies, 26, 587-602.

Damanpour, F., Walker, R. M., \& Avellaneda, C. N. (2009). Combinative Effects of Innovation Types and Organizational Performance: A Longitudinal Study of Service Organizations. Journal of Management Studies, 46, 650-675.

Damanpour, F., \& Wischnevsky, J. D. (2006). Research on innovation in organizations: Distinguishing innovation-generating from innovation-adopting organizations. Journal of Engineering and Technology Management, 23, 269-291. 
Day, G. S. (1994). The Capabilities of Market-Driven Organizations. Journal of Marketing, $58,37-52$.

Dess, G. G., \& Robinson, R. B., Jr. (1984). Measuring Organizational Performance in the Absence of Objective Measures: The Case of the Privately-Held Firm and Conglomerate Business Unit. Strategic Management Journal, 5, 265-273.

Dhanaraj, C., \& Beamish, P. W. (2003). A Resource-Based Approach to the Study of Export Performance. Journal of Small Business Management, 41, 242-261.

Droge, C., Calantone, R., \& Harmancioglu, N. (2008). New Product Success: Is It Really Controllable by Managers in Highly Turbulent Environments? Journal of Product Innovation Management, 25, 272-286.

Evans, J., \& Mavondo, F. T. (2002). Psychic Distance and Organizational Performance: An Empirical Examination of International Retailing Operations. Journal of International Business Studies, 33, 515-532.

Evans, J., Mavondo, F. T., \& Bridson, K. (2008). Psychic Distance: Antecedents, Retail Strategy Implications, and Performance Outcomes. Journal of International Marketing, 16, 32-63.

Fiske, D. W. (1982). Convergent-Discriminant Validation in Measurements and Research Strategies. New Directions for Methodology of Social \& Behavioral Science, 12, 7792.

Fornell, C., \& Larcker, D. F. (1981). Evaluating Structural Equation Models with Unobservable Variables and Measurement Error. Journal of Marketing Research, 18, 39-50.

Forsgren, M. (2002). The Concept of Learning in the Uppsala Internationalization Process Model: A Critical Review. International Business Review, 11, 257-277.

Freeman, C., \& Soete, L. (2009). Developing Science, Technology and Innovation Indicators: What We Can Learn from the Past. Research Policy, 38, 583-589.

Galizzi, G., \& Venturini, L. (2008). Nature and Determinants of Product Innovation in a Competitive Environment of Changing Vertical Relationships. In R. Rama (Ed.), Handbook of Innovation in the Food and Drink Industry (pp. 51-79). New York: Haworth Press.

Gerbing, D. W., \& Anderson, J. C. (1988). An Updated Paradigm for Scale Development Incorporating Unidimensionality and its Assessment. Journal of Marketing Research, 25, 186-192.

Gereffi, G. (1999). International Trade and Industrial Uppgrading in the Apparel Commodity Chain. Journal of International Economics, 48, 37-70.

Glick, W. H., Huber, G. P., Miller, C. C., Doty, D. H., \& Sutcliffe, K. M. (1990). Studying Changes in Organizational Design and Effectiveness: Retrospective Event Histories and Periodic Assessments. Organization Science, 1, 293-312.

Golgeci, I., \& Ponomarov, S. Y. (2013). Does firm innovativeness enable effective responses to supply chain disruptions? An empirical study. Supply Chain Management: An International Journal, 18, 604-617.

Gopalakrishnan, S. (2000). Unraveling the links between dimensions of innovation and organizational performance. Journal of High Technology Management Research, 11, 137-153.

Govindarajan, V., \& Kopalle, P. K. (2006). The Usefulness of Measuring Disruptiveness of Innovations Ex Post in Making Ex Ante Predictions. Journal of Product Innovation Management, 23, 12-18.

Grant, R. M. (1991). The Resource-Based Theory of Competitive Advantage: Implications for Strategy Formulation. California Management Review, 33, 114-135. 
Guan, J., \& Ma, N. (2003). Innovative Capability and Export Performance of Chinese Firms. Technovation, 23, 737-747.

Gunday, G., Ulusoy, G., Kilic, K., \& Alpkan, L. (2011). Effects of Innovation Types on Firm Performance. International Journal of Production Economics, 133, 662-676.

Haahti, A., Madupu, V., Yavas, U., \& Babakus, E. (2005). Cooperative Strategy, Knowledge Intensity and Export Performance of Small and Medium Sized Enterprises. Journal of World Business, 40, 124-138.

Hair Jr., J. F., Black, W. C., Babin, B. J., \& Anderson, R. E. (2010). Multivariate Data Analysis: A Global Perspective. Upper Saddle River, NJ: Pearson Education.

Hall, B., \& Mairesse, J. (1995). Exploring the Relationship between R\&D and Productivity in French Manufacturing Firms. Journal of Econometrics, 65, 263-293.

Hamel, G. (2006). The Why, What, and How of Management Innovation. Harvard Business Review, 84, 72-84+163.

Han, J. K., Kim, N., \& Srivastava, R. K. (1998). Market Orientation and Organizational Performance: Is Innovation a Missing Link? Journal of Marketing, 62, 30-45.

Hervas-Oliver, J.-L., Albors Garrigos, J., \& Gil-Pechuan, I. (2011). Making Sense of Innovation by $R \& D$ and Non-R\&D Innovators in Low Technology Contexts: A Forgotten Lesson for Policymakers. Technovation, 31, 427-446.

Hirsch-Kreinsen, H. (2008). "Low-Tech" Innovations. Industry and Innovation, 15, 19-43.

Hortinha, P., Lages, C., \& Lages, L. F. (2011). The Trade-Off between Customer and Technology Orientations: Impact on Innovation Capabilities and Export Performance. Journal of International Marketing, 19, 36-58.

Hurley, R. F., \& Hult, G. T. M. (1998). Innovation, Market Orientation, and Organizational Learning: An Integration and Empirical Examination. Journal of Marketing, 62, 4254.

Jarvis, Cheryl B., MacKenzie, Scott B., \& Podsakoff, Philip M. (2003). A Critical Review of Construct Indicators and Measurement Model Misspecification in Marketing and Consumer Research. Journal of Consumer Research, 30, 199-218.

Johanson, J., \& Vahlne, J. E. (1977). The Internationalization Process of the Firm - A Model of Knowledge Development and Increasing Foreign Market Commitments. Journal of International Business Studies, 8, 23-32.

Johanson, J., \& Vahlne, J. E. (2009). The Uppsala Internationalization Process Model Revisited: From Liability of Foreignness to Liability of Outsidership. Journal of International Business Studies, 40, 1411-1431.

Jöreskog, K. G., \& Sörbom, D. (2006). LISREL 8.80 for Windows. Lincolnwood, IL: Scientific Software International, Inc.

Junkunc, M. T. (2007). Managing Radical Innovation: The Importance of Specialized Knowledge in the Biotech Revolution. Journal of Business Venturing, 22, 388-411.

Kafouros, M. I., Buckley, P. J., Sharp, J. A., \& Wang, C. Q. (2008). The Role of Internationalization in Explaining Innovation Performance. Technovation, 28, 63-74.

Katsikeas, C. S., Leonidou, L. C., \& Morgan, N. A. (2000). Firm-Level Export Performance Assessment: Review, Evaluation, and Development. Journal of the Academy of Marketing Science, 28, 493-511.

Katsikeas, C. S., Piercy, N. F., \& Ioannidis, C. (1996). Determinants of Export Performance in a European Context. European Journal of Marketing, 30, 6-35.

Kimberly, J. R., \& Evanisko, M. J. (1981). Organizational Innovation: The Influence of Individual, Organizational, and Contextual Factors on Hospital Adoption of Technological and Administrative Innovations. Academy of Management Journal, 24, 689-713. 
Lages, L. F., Jap, S. D., \& Griffith, D. A. (2008). The Role of Past Performance in Export Ventures: A Short-Term Reactive Approach. Journal of International Business Studies, 39, 304-325.

Lages, L. F., Lages, C., \& Lages, C. R. (2005). Bringing Export Performance Metrics into Annual Reports: The APEV Scale and the PERFEX Scorecard. Journal of International Marketing, 13, 79-104.

Lages, L. F., Silva, G., \& Styles, C. (2009). Relationship Capabilities, Quality, and Innovation as Determinants of Export Performance. Journal of International Marketing, 17, 47-70.

Lam, A. (2005). Organizational Innovation. In J. Fagerberg, D. C. Mowery \& R. R. Nelson (Eds.), The Oxford Handbook of Innovation (pp. 115-147). Oxford: Oxford University Press.

Lawrence, P. R., \& Lorsch, J. W. (1967). Organization and Environment: Managing Differentiation and Integration. Illinois: Irwin, Homewood.

Lee, H., Smith, K. G., \& Grimm, C. M. (2003). The effect of new product radicality and scope on the extent and speed of innovation diffusion. Journal of Management, 29, 753-768.

Leonidou, L. C., Katsikeas, C. S., \& Samiee, S. (2002). Marketing Strategy Determinants of Export Performance: A Meta-Analysis. Journal of Business Research, 55, 51-67.

Love, J. H., \& Ashcroft, B. (1999). Market Versus Corporate Structure in Plant-Level Innovation Performance. Small Business Economics, 13, 97-109.

Macmillan, I., McCaffery, M. L., \& Wijk, G. v. (1985). Competitors' Responses to Easily Imitated New Products-Exploring Commercial Banking Product Introductions. Strategic Management Journal, 6, 75-86.

Matanda, M. J., \& Freeman, S. (2009). Effect of Perceived Environmental Uncertainty on Exporter-Importer Inter-Organisational Relationships and Export Performance Improvement. International Business Review, 18, 89-107.

McDermott, C. M., \& O'Connor, G. C. (2002). Managing radical innovation: An overview of emergent strategy issues. Journal of Product Innovation Management, 19, 424-438.

Mendonca, S. (2009). Brave Old World: Accounting for 'High-Tech' Knowledge in 'LowTech' Industries. Research Policy, 38, 470-482.

Miller, D., \& Friesen, P. H. (1982). Innovation in Conservative and Entrepreneurial Firms: Two Models of Strategic Momentum. Strategic Management Journal, 3, 1-25.

Mol, M. J., \& Birkinshaw, J. (2009). The Sources of Management Innovation: When Firms Introduce New Management Practices. Journal of Business Research, 62, 1269-1280.

Moorman, C., \& Miner, A. S. (1997). The Impact of Organizational Memory on New Product Performance and Creativity. Journal of Marketing Research, 34, 91-106.

Morgan, N. A., Kaleka, A., \& Katsikeas, C. S. (2004). Antecedents of Export Venture Performance: A Theoretical Model and Empirical Assessment. Journal of Marketing, 68, 90-108.

Nam, D.-i., Parboteeah, K. P., Cullen, J. B., \& Johnson, J. L. (2014). Cross-National Differences in Firms Undertaking Innovation Initiatives: An Application of Institutional Anomie Theory. Journal of International Management, 20, 91-106.

Nijssen, E. J., Hillebrand, B., \& Vermeulen, P. A. M. (2005). Unraveling Willingness to Cannibalize: A Closer Look at the Barrier to Radical Innovation. Technovation, 25, 1400-1409.

O'Cass, A., \& Weerawardena, J. (2009). Examining the Role of International Entrepreneurship, Innovation and International Market Performance in SME Internationalisation. European Journal of Marketing, 43, 1325-1348. 
O'Connor, G. C., \& Rice, M. P. (2013). A Comprehensive Model of Uncertainty Associated with Radical Innovation. Journal of Product Innovation Management, 30, 2-18.

O'Connor, G. C., \& Veryzer, R. W. (2001). The Nature of Market Visioning for TechnologyBased Radical Innovation. Journal of Product Innovation Management, 18, 231-246.

OECD. (2005). The Measurement of Scientific and Technological Activities Oslo Manual. Guidelines for Collecting and Interpreting Innovation Data. In (3rd ed.). Paris: OECD EUROTAT.

Papadopoulos, N., \& Martín Martín, O. (2010). Toward a Model of the Relationship between Internationalization and Export Performance. International Business Review, 19, 388406.

Pla-Barber, J., \& Alegre, J. (2007). Analysing the Link between Export Intensity, Innovation and Firm Size in a Science-Based Industry. International Business Review, 16, 275293.

Podsakoff, P. M., MacKenzie, S. B., Lee, J.-Y., \& Podsakoff, N. P. (2003). Common Method Biases in Behavioral Research: A Critical Review of the Literature and Recommended Remedies. Journal of Applied Psychology, 88, 879-903.

Powell, W. W., \& Grodal, S. (2005). Networks of Innovators. In J. Fagerberg, D. C. Mowery \& R. R. Nelson (Eds.), The Oxford Handbook of Innovation (pp. 56-85). Oxford: Oxford University Press.

Rama, R. (2008). Handbook of Innovation in the Food and Drink Industry. New York: Haworth Press.

Reinders, M. J., Frambach, R. T., \& Schoormans, J. P. L. (2010). Using product bundling to facilitate the adoption process of radical innovations. Journal of Product Innovation Management, 27, 1127-1140.

Robertson, C., \& Chetty, S. K. (2000). A Contingency-Based Approach to Understanding Export Performance. International Business Review, 9, 211-235.

Robson, C. (2011). Real World Research: A Resource for Users of Social Research Methods in Applied Settings. Chichester: Wiley.

Roper, S., \& Love, J. H. (2002). Innovation and Export Performance: Evidence from the UK and German Manufacturing Plants. Research Policy, 31, 1087-1102.

Sainio, L. M., Ritala, P., \& Hurmelinna-Laukkanen, P. (2012). Constituents of Radical Innovation - Exploring the Role of Strategic Orientations and Market Uncertainty. Technovation, 32, 591-599.

Salomon, R., \& Jin, B. (2008). Does Knowledge Spill to Leaders or Laggards? Exploring Industry Heterogeneity in Learning by Exporting. Journal of International Business Studies, 39, 132-150.

Sanidas, E. (2005). Organizational Innovations and Economic Growth: Organosis and Growth of Firms, Sectors, and Countries. Cheltenham: Edward Elgar.

Shefer, D., \& Frenkel, A. (2005). R\&D, Firm Size and Innovation: An Empirical Aanalys is. Technovation, 25, 25-32.

Singh, D. A. (2009). Export Performance of Emerging Market Firms. International Business Review, 18, 321-330.

Sousa, C. M. P. (2004). Export Performance Measurement: An Evaluation of the Empirical Research in the Literature. Academy of Marketing Science Review, 2004, 1.

Sousa, C. M. P., Lengler, J. F. B., \& Martínez-López, F. J. (2014). Testing for Linear and Quadratic Effects between Price Adaptation and Export Performance: The Impact of Values and Perceptions. Journal of Small Business Management, 52, 501-520.

Sousa, C. M. P., Martínez-López, F. J., \& Coelho, F. (2008). The Determinants of Export Performance: A Review of the Research in the Literature between 1998 and 2005. International Journal of Management Reviews, 10, 343-374. 
Statistics Sweden. (2012). Trade in Goods and Services: Imports and Exports of Goods by Commodity Groups SITC. Retreived $10^{\text {th }}$ February 2012, from http://scb.se/en_/Finding-statistics/Statistics-by-subject-area/Trade-in-goods-andservices/Foreign-trade/Foreign-trade---exports-and-imports-of-goods.

Stoian, M. C., Rialp, A., \& Rialp, J. (2011). Export Performance under the Microscope: A Glance through Spanish Lenses. International Business Review, 20, 117-135.

Story, V. M., Boso, N., \& Cadogan, J. W. (2015). The Form of Relationship between FirmLevel Product Innovativeness and New Product Performance in Developed and Emerging Markets. Journal of Product Innovation Management, 32, 45-64.

Subramanian, A. (1996). Innovativeness: Redefining the Concept. Journal of Engineering and Technology Management, 13, 223-243.

Teece, D. J. (2007). Explicating Dynamic Capabilities: The Nature and Microfoundations of (Sustainable) Enterprise Performance. Strategic Management Journal, 28, 1319-1350.

Teece, D. J. (2010). Business models, business strategy and innovation. Long Range Planning, 43, 172-194.

Tellis, G. J., Prabhu, J. C., \& Chandy, R. K. (2009). Radical Innovation Across Nations: The Preeminence of Corporate Culture. Journal of Marketing, 73, 3-23.

Venkatraman, N., \& Ramanujam, V. (1987). Measurement of Business Economic Performance: An Examination of Method Convergence. Journal of Management, 13, 109-122.

Wagner, J. (1995). Exports, Firm size, and Firm Dynamics. Small Business Economics, 7, 2939.

Wagner, J. (2001). A Note on the Firm Size-Export Relationship. Small Business Economics, $17,229-237$.

Wakasugi, R. (1992). Why are Japanese firms so innovative in engineering technology? Research Policy, 21, 1-12.

Walker, R. M. (2004). Innovation and Organisational Performance: Evidence and a Research Agenda. Retreived $1^{\text {st }}$ July 2015, from http://www.aimresearch.org.

Wang, C. H., Lu, I. y., \& Chen, C. b. (2008). Evaluating Firm Technological Innovation Capability under Uncertainty. Technovation, 28, 349-363.

Wang, Y., Cao, W., Zhou, Z., \& Ning, L. (2013). Does External Technology Acquisition Determine Export Performance? Evidence from Chinese Manufacturing Firms. International Business Review, 22, 1079-1091.

Weerawardena, J. (2003a). Exploring the Role of Market Learning Capability in Competitive Strategy. European Journal of Marketing, 37, 407-429.

Weerawardena, J. (2003b). The Role of Marketing Capability in Innovation-Based Competitive Strategy. Journal of Strategic Marketing, 11, 15-35.

World Bank. (2014). World Development Indicators. Retreived $2^{\text {nd }}$ May 2014, from http://data.worldbank.org/ind icator/NE.EXP.GNFS.ZS/countries.

Zahra, S. A., \& Covin, J. G. (1995). Contextual Influences on the Corporate Entrepreneurship-Performance Relationship: A Longitudinal Analysis. Journal of Business Venturing, 10, 43-58.

Zeithaml, V. A., \& Zeithaml, C. P. (1988). The Contingency Approach: Its Foundations and Relevance to Theory Building and Research in Marketing. European Journal of Marketing, 22, 37-64.

Zhou, K. Z., \& Li, C. B. (2012). How Knowledge Affects Radical Innovation: Knowledge Base, Market Knowledge Acquisition, and Internal Knowledge Sharing. Strategic Management Journal, 33, 1090-1102. 
Zhou, L., Wu, W.-p., \& Luo, X. (2007). Internationalization and the Performance of BornGlobal SMEs: The Mediating Role of Social Networks. Journal of International Business Studies, 38, 673-690. 
Figure 1. The Conceptual Model

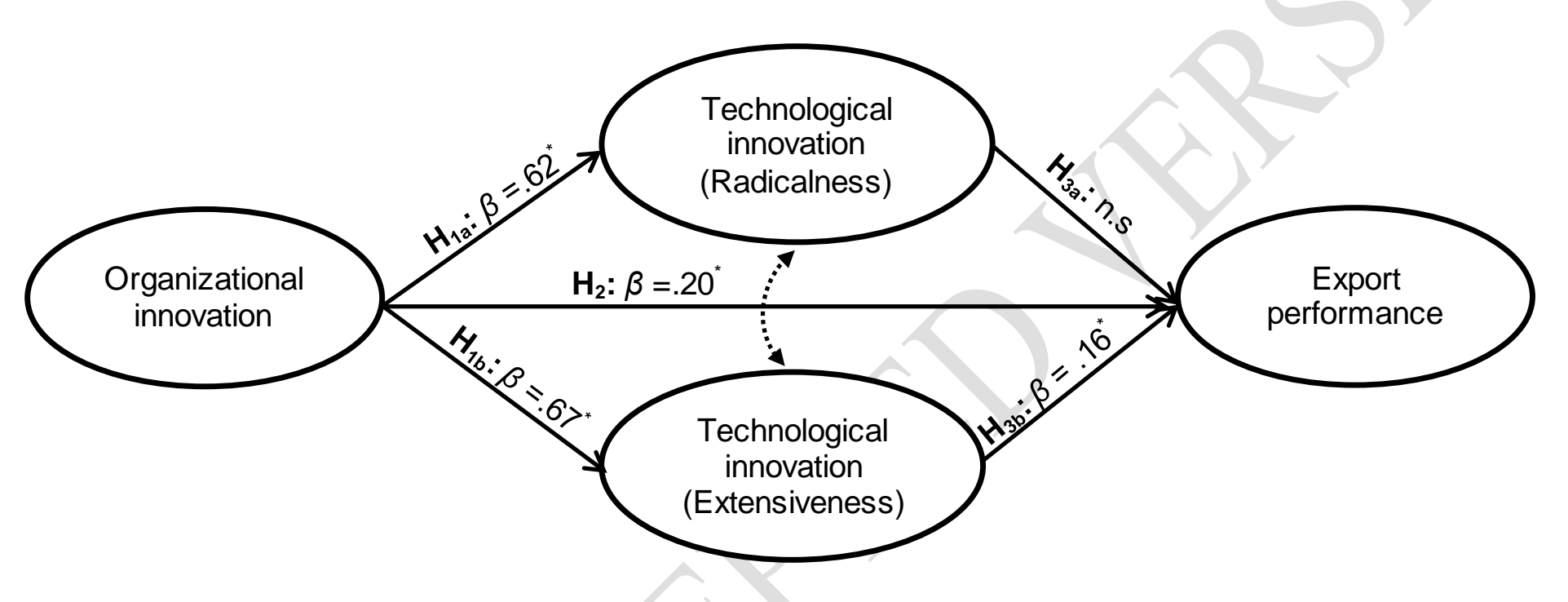

Notes: $\chi 2=24.79(15$ d.f., $\mathrm{p}=.005279) ; \mathrm{RMSEA}=.055 ; \mathrm{NFI}=.96 ; \mathrm{CFI}=.98 ; \mathrm{IFI}=.98 ; \mathrm{RFI}=.88 ; \mathrm{SRMR}=.033$; $\mathrm{GFI}=.98$; AGFI $=.92 . *$ Significant at the .05 level; $\mathrm{n} . \mathrm{s}=$ non-significant; RMSEA $=$ root mean square of approximation; NFI = normed fit index; $\mathrm{CFI}=$ comparative fit index; $\mathrm{IFI}=$ incremental fit index; RFI = relative fit index; SRMR $=$ standardized root mean residual; GFI $=$ goodness of fit index; and AGFI $=$ adjusted goodness of fit index. We controlled for firm size, industry type, host country's R\&D expenditure (\% of GDP), its extent of development, and (perceived) differences in relation to the home market. 
Table 1. Items, reliability, and average variance extracted

Construct and items

Loadings

Technological innovation ${ }^{1}$ (adapted from Weerawardena 2003a; 2003b) (Second-order) (AVE $=.580, \mathrm{CR}=.657, \alpha=0.84$ )

PRODUCT_EXT Product innovations introduced by our firm during the last three years have been ... (Scale: $1=$ limited and $7=$ extensive)

PRODUCT_RAD Product innovations have mainly been $\ldots$.. (Scale: $1=$ incremental and $7=$ radical)

PROCESS_EXT Process innovations introduced by our firm during the last three years have been $\ldots$.. (Scale: $1=$ limited and $7=$ extensive)

PROCESS_RAD Process innovations have mainly been $\ldots$ (Scale: $1=$ incremental and $7=$ radical)

Organizational innovation ${ }^{2}$ (adapted from Weerawardena 2003a; 2003b) (Second-order) (AVE $=.521, \mathrm{CR}=.731, \alpha=0.879$ )

MANAGE_EXT Managerial innovations introduced by our firm during the last three years have been ... (Scale: $1=$ limited and $7=$ extensive)

MANAGE_RAD Managerial innovations have mainly been $\ldots$.. (Scale: $1=$ incremental and $7=$ radical)

MARKETING_EXT Marketing innovations introduced by our firm during the last three years have been ... (Scale: $1=$ limited and $7=$ extensive)

MARKETING_RAD Marketing innovations have mainly been ... (Scale: $1=$ incremental and $7=$ radical)

Export performance (adapted from Evans and Mavondo 2002; Evans et al. 2008)

Financial performance $(\mathrm{AVE}=.790, \mathrm{CR}=.879, \alpha=0.929)$

Question: To what extent have the following financial indicators changed for your company in the past three years in the nominated markets? (Scale: $1=$ decrease of more than $20 \%$ and $7=$ increase of more than $20 \%$ )

PE F1 Return on assets

PE_F2 Return on investment

PE_F3 Return on sales

PE F4 Sales

Strategic effectiveness $(\mathrm{AVE}=.816, \mathrm{CR}=.855, \alpha=0.921)$

Question: How successful has your company been regarding the following in relation to the nominated markets in the past three years? (Scale: $1=$ very unsuccessful and $7=$ very successful)

PE_S1 Achievement of strategic objectives

PE_S2 Satisfaction with overall performance

\section{Control variables}

Firm size (ln number of full-time employees) 
Industry type

R\&D expenditure (\% of GDP)

Extent of development (GNI)

Foreign market (perceived) differences (dummy)

Notes: AVE = average variance extracted (Fornell and Larcker 1981); CR = construct reliability (Bagozzi 1980); $\alpha$ = Cronbach's coefficient alpha; ln = natural logarithm; 'e.g., improving existing products, creating new products, introducing computer-based production application, automated material handling, introducing manufacturing information systems; ${ }^{2}$ e.g., introducing computer-based administrative applications, developing new employee rewarding schemes, obtaining new financing sources, introducing new departments or project teams, introducing new pricing methods, new distribution methods, new sales approaches or leasing arrangements.

Table 2. Correlations, means, and standard deviations

\begin{tabular}{|c|c|c|c|c|c|c|c|c|c|c|c|c|}
\hline Constructs/Variables & Mean & SD & 1 & 2 & 3 & 4 & 5 & 6 & 7 & 8 & 9 & 10 \\
\hline Technological innovation radicalness & 5.47 & 2.92 & 1 & & & & & & & & & \\
\hline Technological innovation extensiveness & 5.80 & 2.73 & $.816^{* *}$ & 1 & & & & & & & & \\
\hline Organizational innovation & 10.13 & 5.13 & $.677^{* * \pi}$ & $.627^{* \pi}$ & 1 & & & & & & & \\
\hline Financial performance & 16.16 & 4.96 & $.204^{* *}$ & $.157^{*}$ & $.160^{*}$ & 1 & . & & & & & \\
\hline Strategic effectiveness & 7.20 & 3.17 & $.415^{* *}$ & $.425^{* *}$ & $.422^{* *}$ & $.656^{* *}$ & 1 & & & & & \\
\hline Firm size & 3.09 & 1.66 & $.172^{*}$ & $.245^{* *}$ & $.256^{* *}$ & $.162^{*}$ & $.299^{* * *}$ & 1 & & & & \\
\hline Industry type & 4.27 & 1.54 & .069 & .004 & .009 & $-.156^{*}$ & -.129 & $-.158^{*}$ & 1 & & & \\
\hline 8. $\quad \mathrm{R} \& \mathrm{D}$ expenditure & 2.28 & .92 & -.088 & -.108 & -.022 & -.084 & -.109 & -.043 & -.115 & 1 & & \\
\hline 9. Extent of development & 1.09 & .28 & $.184^{* *}$ & .119 & .094 & .073 & .029 & .044 & -.068 & $-.423^{* *}$ & 1 & \\
\hline 10. Foreign market (perceived) differences & 1.45 & .49 & -.024 & -.044 & .019 & -.112 & -.103 & .011 & -.028 & -.132 & $.348^{* *}$ & 1 \\
\hline
\end{tabular}

Notes: ${ }^{*}$ Correlation is significant at the .05 level (2-tailed). ${ }^{* *}$ Correlation is significant at the .01 level (2-tailed). $\mathrm{SD}=$ standard deviation. 
Appendix A. Export markets covered by the study

\begin{tabular}{llll}
\hline Export markets & & \\
\hline Australia & Finland & Latvia & Russia \\
Belgium & France & Lebanon & Spain \\
Bosnia and Herzegovina & Germany & Lithuania & United Kingdom \\
Canada & Ghana & Netherlands & United States of America \\
China & Iceland & Norway & Venezuela \\
Denmark & Italy & Panama & \\
Estonia & Japan & Qatar & \\
\hline
\end{tabular}

Appendix B. Sample characteristics

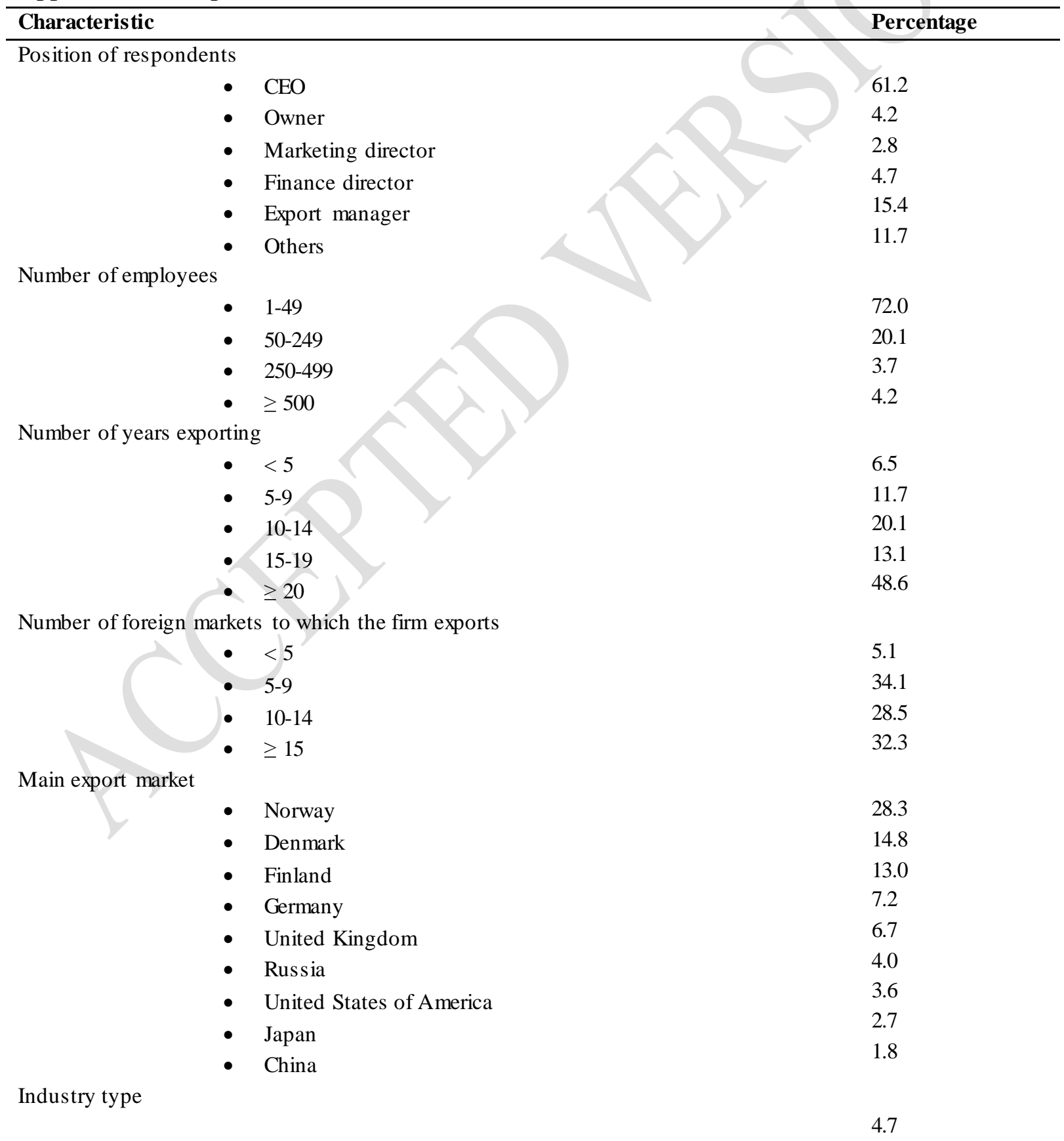




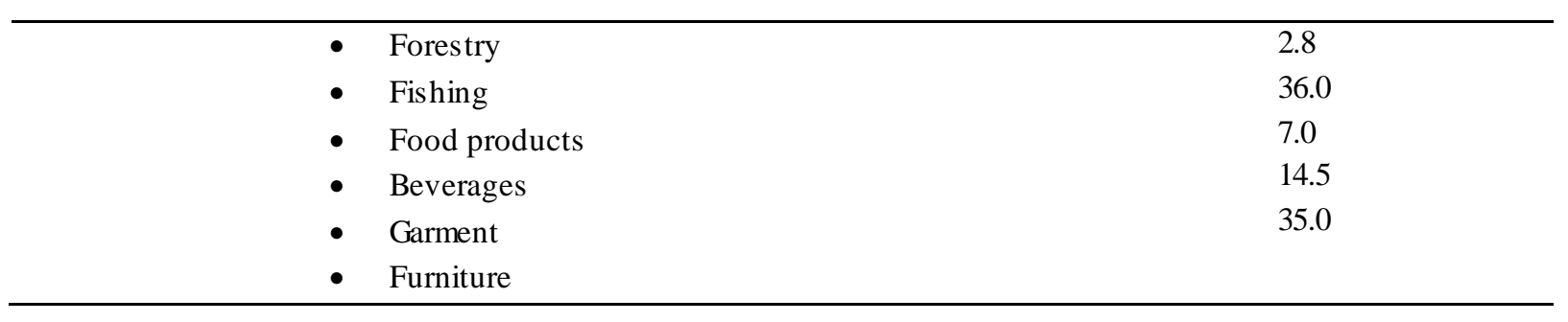

